\title{
Effect of Different Age of Rootstock on Grafting of Jackfruit (Artocarpus heterophyllus L.) var.Palur-1
}

\author{
K.E. Naik ${ }^{*}$ and C. Subesh Ranjith Kumar \\ Department of Fruit Crops, Horticultural College and Research Institute, Tamil Nadu \\ Agricultural University, Periyakulam - 625 604, Tamil Nadu, India \\ *Corresponding author
}

\section{A B S T R A C T}

\section{Keywords}

Rootstock, Jackfruit (Artocarpus heterophyllus L.)

Article Info

Accepted:

22 July 2018

Available Online:

10 August 2018
An experiment was conducted during 2016-17 at Department of Fruit Crops, Horticultural College and Research Institute, Periyakulam for determining the age of rootstock for grafting in jackfruit by softwood grafting method. Experiment was laid out on Factorial Completely Randomized Design (FCRD) with three replications. Growth parameters like days taken for graft union, graft success (\%), days taken for sprouting, number of sprouts, length of sprouts $(\mathrm{cm})$, plant height $(\mathrm{cm})$, girth of rootstock $(\mathrm{cm})$, girth of scion $(\mathrm{cm})$, number of leaves, leaf length $(\mathrm{cm})$, breadth of leaf $(\mathrm{cm})$, leaf area $\left(\mathrm{cm}_{2}\right)$, graft survival $(\%)$ at 30, 60 and 90 days after grafting were recorded. On comparing the performance of different age of rootstocks used, 30 days old rootstock gave successful grafts and improved growth parameters. Physiological parameters also showed positive response in 30 days old rootstock.

\section{Introduction}

Jackfruit is a popular fruit in several tropical and sub-tropical countries. It is regarded as "poor man's fruit" in eastern and southern parts of India. Jackfruit is believed to be native of India, originating in Western Ghats and is widely cultivated in Malaysia, Myanmar, Indonesia, Bangladesh, Sri Lanka, Brazil, West Indies, Vietnam, Pakistan and other tropical countries (Bose and Mitra, 2002; Anonymous, 2009). In India, the total area under jackfruit cultivation is approximately 1,51,000 hectares (Source: Ministry of Agriculture and Farmers welfare, 2016). In Tamil Nadu, jack fruit is considered as the second most important fruit after mango in the triple fruit concept (Mango, Jackfruit and Banana) mentioned in Hindu scriptures.

Huge variability exists in this crop due to seed propagation. Among the various constraints for expanding the jackfruit cultivation, lack of availability of suitable clonal planting materials is one of the impediments to expand the area of cultivation (Anonymous, 2009). There is great demand for genuine true-to-type planting materials in order to optimize production of quality fruits. For this reason vegetative propagation is essential to get trueto-type propagules. So the quality planting materials having uniform characters are the utmost demand of the farmers nowadays, hence standardization of suitable vegetative 
propagation technique with age of scion and rootstocks is prerequisite for successful cultivation and also will help in fixing the characters of superior types (Bose and Mitra, 2002).

\section{Materials and Methods}

The studies on softwood grafting in jackfruit plants were carried out during 2016-17 at the Department of Fruit crops, Horticultural College and Research Institute, Tamil Nadu Agricultural University, Periyakulam. The experiment location is situated at an elevation of $300 \mathrm{~m}$ above mean sea level, at 100 North Latitude and 77.80 East Latitude. Seeds were collected from local and the rootstocks were raised in polythene bags. Scions of Palur-1 jackfruit variety were grafted in the raised rootstock in different period. Plumpy and healthy jack seeds weighing about 4 to $7 \mathrm{~g}$ were collected from local and were utilized for raising seedling rootstock. These seeds were soaked in water for 24 hours to enhance germination and then sown in the polythene bags.

Polythene bags of 250 gauge (5"-7") thickness were used for raising jack rootstocks. The pot mixture for rooting medium was prepared with red earth, sand, well decomposed farmyard manure (2: 1: 1) and filled in the poly bag. The selected large sized healthy seeds were laid flat on the medium with their hilum part facing down. The pot mixture for rooting medium was prepared with red earth, sand, well decomposed farmyard manure $(2: 1: 1)$ and filled in the poly bag. The selected large sized healthy seeds were laid flat on the medium with their hilum part facing down. The seeds which were sown in the polythene bags and the softwood grafts were grown in different growing conditions viz., mist chamber (C1) and shade net house (C2). Grafting parameters and physical parameters were recorded at three different stages viz., $30^{\text {th }}, 60^{\text {th }}$ and $90^{\text {th }}$ days after grafting. The grafting operation was done at 15 days interval using procured scion sticks of Palur-1 jack on the raised rootstock.

\section{Results and Discussion}

In this study, an attempt has been made to propagate Palur-1 (Scion) the ruling variety of Tamil Nadu through softwood grafting with different age of rootstocks. Number of days taken for the union influenced significantly by the age of rootstocks in mist chamber. Grafting done on 30 days old rootstock took the least number of days for graft union (24.07 days) and the maximum number of 27.96 days taken for graft union grafting on 135 days old rootstock (Table 1). The maximum graft union success was reported in case of 30 days old rootstocks in both the mist chamber and shade net house conditions. This might be due to the prevailing optimum temperatures coupled with higher humidity experienced in the November month resulting in early contact of cambium layers of stock and scion. More over the 30 days old rootstock recorded the maximum success rate of 85.40 per cent on $30^{\text {th }}$ day and also gave earlier sprouting (19.20 days) (Table $1)$. It is due to the preservation of more food materials in cotyledon and actively growing stage of rootstock that enhance union in grafting. These results were on agreement with the findings of Jose and Valsalakumari (1991) and Dhar (1998). The sprouting of scions in the grafted union has a direct impact with the precured scions used for the grafting. The beneficial effect of precuring is well recognized in crops like cashew nut (Swamy, 1993) and jackfruit (Maiti and Sen, 1999) to enhance the graft success. Maximum plant height $(15.67 \mathrm{~cm})$ was obtained in the 30 day's old rootstock (Table 1). This might be due to the scion quality collected during the month of November 2016 coincides with the North East monsoon rain fall falls on during October 2016. 
Table.1 Effect of different age of rootstocks on growth parameters of jackfruit

\begin{tabular}{|c|c|c|c|c|c|c|c|c|c|}
\hline $\begin{array}{c}\text { Treatment } \\
\text { (T) }\end{array}$ & $\begin{array}{l}\text { Graft } \\
\text { union } \\
\text { (days) } \\
\text { 30DAG }\end{array}$ & $\begin{array}{c}\text { Graft } \\
\text { success } \\
(\%) \\
30 \text { DAG }\end{array}$ & $\begin{array}{l}\text { Days taken } \\
\text { for } \\
\text { sprouting }\end{array}$ & $\begin{array}{c}\text { Plant } \\
\text { height } \\
\text { (cm) } \\
\text { 30 DAG }\end{array}$ & $\begin{array}{l}\text { Number } \\
\text { of leaves } \\
30 \text { DAG }\end{array}$ & $\begin{array}{l}\text { Leaf } \\
\text { length } \\
(\mathrm{cm}) \\
\text { 30DAG }\end{array}$ & $\begin{array}{l}\text { Leaf } \\
\text { breadth } \\
\text { 30DAG }\end{array}$ & $\begin{array}{c}\text { Leaf area } \\
\left(\mathrm{cm}^{2}\right) \\
\text { 30DAG }\end{array}$ & $\begin{array}{c}\text { Graft } \\
\text { survival } \\
\text { percentage } \\
(\%)\end{array}$ \\
\hline $\mathbf{A 1}$ & 26.71 & 71.54 & 19.99 & 12.39 & 1.95 & 2.22 & 0.80 & 2.15 & 63.86 \\
\hline $\mathbf{A 2}$ & 24.07 & 85.40 & 19.20 & 15.67 & 2.76 & 3.27 & 1.06 & 2.38 & 69.09 \\
\hline A3 & 26.86 & 71.44 & 19.74 & 13.39 & 1.92 & 2.71 & 0.90 & 2.26 & 61.92 \\
\hline $\mathbf{A 4}$ & 26.66 & 77.92 & 20.20 & 12.51 & 2.26 & 2.24 & 0.84 & 2.08 & 58.21 \\
\hline $\mathbf{A 5}$ & 26.69 & 81.45 & 19.98 & 13.31 & 2.13 & 2.34 & 0.76 & 1.76 & 68.54 \\
\hline A6 & 26.76 & 75.69 & 20.00 & 14.30 & 2.06 & 1.95 & 0.74 & 1.43 & 65.39 \\
\hline $\mathbf{A 7}$ & 27.56 & 71.25 & 20.21 & 12.26 & 1.48 & 1.70 & 0.86 & 1.39 & 59.36 \\
\hline A8 & 27.30 & 69.98 & 20.09 & 10.95 & 1.49 & 1.65 & 0.73 & 2.14 & 55.83 \\
\hline $\mathbf{A 9}$ & 27.96 & 66.31 & 20.87 & 9.69 & 1.26 & 1.58 & 0.71 & 1.35 & 50.85 \\
\hline Mean & 26.72 & 74.71 & 20.03 & 12.71 & 1.92 & 2.17 & 0.82 & 1.88 & 61.44 \\
\hline S.Ed & 0.271 & 2.920 & 0.337 & 0.691 & 0.084 & 0.098 & 0.027 & 0.088 & 1.236 \\
\hline CD@0.05 & 0.552 & NS & 0.686 & 1.408 & 0.171 & 0.200 & 0.116 & 0.187 & 5.338 \\
\hline
\end{tabular}

A1: 15 DORS, A2:30 DORS, A3: 45 DORS, A4: 60 DORS, A5:75 DORS, A6: 90 DORS, A7: 105 DORS, A8: 120 DORS, A9: 135 DORS DORS - Days Old Root Stock

DAG - Days After Grafting,

NS: Non significant 
Table.2 Leaf chlorophyll content and total phenol content at different age of Rootstock before grafting

\begin{tabular}{|c|c|c|}
\hline Treatment $(\mathrm{T})$ & Leaf chlorophyll content $(\mathrm{mg} / \mathrm{g})$ & Total Phenol content $(\mathrm{mg} / \mathrm{g})$ \\
\hline A1 & 15.41 & 2.04 \\
\hline A2 & 18.22 & 2.15 \\
\hline A3 & 21.28 & 2.61 \\
\hline A4 & 24.66 & 3.62 \\
\hline A5 & 28.23 & 3.84 \\
\hline A6 & 33.40 & 4.52 \\
\hline A7 & 39.45 & 4.58 \\
\hline A8 & 47.25 & 5.26 \\
\hline A9 & 52.62 & 5.44 \\
\hline
\end{tabular}

30 days oldrootstock

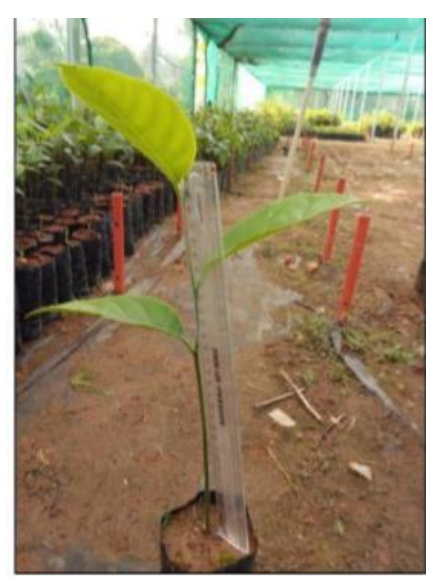

Precuredscion

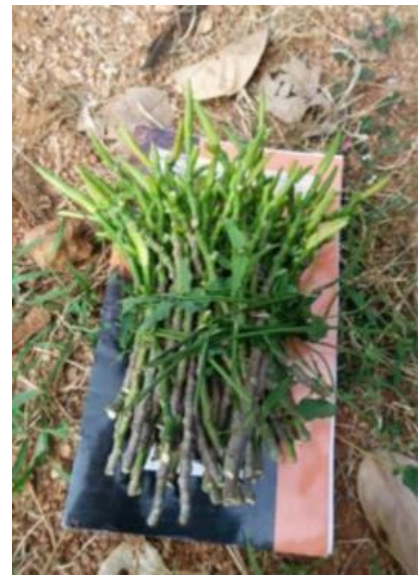

Grafts

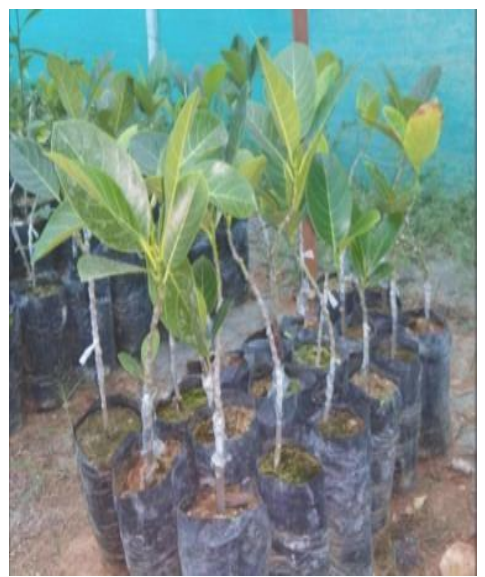

These conditions favoured better growth of new flushes, consequently the change in the endogenous hormonal level as reported by Priyanka et al., (2017) in jackfruit. Maximum number of leaves (2.76 days) and highest leaf length $(3.27 \mathrm{~cm})$, leaf breadth $(1.06 \mathrm{~cm})$, leaf area $(2.38 \mathrm{~cm} 2)$ were observed in 30 days old rootstock (Table 1). The highest magnitude in number of leaves on 30th, $60^{\text {th }}$ and $90^{\text {th }}$ days after grafting was found in 30 days old rootstock which might be due to earliest sprouting and appropriate time of grafting. This suggest thatthe 30 days old rootstocks might be having the adequate biochemical constituents like carbohydrates, auxin etc., to initiate the proliferation of callus cells at the graft interface leading to formation of callus bridge and vascular differentiation across the graft interface, resulting in more graft success. Maximum graft survival percentage (69.90 per cent) was observed on 30 days old rootstock (Table 1). This happens because the grafting time might have favoured the information of new cambial layer in the cambium bridge at the right time and laying down new secondary xylem toward the inside and phloem toward the outside in deriving the vascular connection. This process of completion before the new bud and leaves formation ensured highest survival percentage in the present study. The work of Gholap Supriya et al., (2015) in mango, Prajapati et al., (2014) on mango was in support with present study. 
The highest leaf chlorophyll $(52.62 \mathrm{mg} / \mathrm{g})$ and total phenol content $(5.44 \mathrm{mg} / \mathrm{g})$ was registered in 135 days old rootstock while the lowest phenol content was recorded in 15 days old $(2.04 \mathrm{mg} / \mathrm{g})$ followed by 30 days old rootstock $(2.15 \mathrm{mg} / \mathrm{g}$ ) (Table 2). The leaf chlorophyll content is an important physiological parameter as it directly influences the photosynthesis and reflect in the size of the leaf. The significant difference observed in leaf chlorophyll content in the present study before the time of grafting might be due to the increase in the photosynthesis efficiency of leaves and the results are in agreement with Chandan et al., (2006). The variation in the presence of phenol content in the different age of root stocks showed it influence on the graft union success. The low phenol content is registered at 30 days old rootstock which might be one of the reasons to get higher graft success (\%) and the result is in line with the work of Selvi (2008). From this study, it could be inferred that 30 days old rootstock is more suitable in producing successful softwood grafts of Palur-1 jackfruit which can be recommended during the month of November using precured scions.

\section{References}

Anonymous. 2009. Jacks Special (Kannada). Adike Patrike, 21(7): 1- 38.

Bose, T. K. and Mitra, S.K. 2002. Jackfruit in Tropical and Subtropical fruits, Naya Udyog Calcutta, 2: 95-97.

Chandan, P.M., J.H. Kadam and Ambad, S. N. 2006. Effect of different polyembryonic and monoembryonic rootstocks on performance of Dashehari mango. Intl. J. Agric. Sci., 2(2):594-595.

Dhar, M. 1998. Techniques of vegetative and in vitro propagation of jack fruit. Ph.D. dissertation. Institute of Postgraduate Studies in Agriculture (IPSA), Salna, Gagipur, Bangladesh, pp: 151

Gholap Supriya, S. and Polara, N. D. 2015. Effect of growing media and storage of stone on the success and survival of soft wood grafting in Mango (Mangifera indica L.)The American Journal of science and medical research. Acta Hort, 989: 264-267.

Jose, M. and Valsalakumari, P.K. 1991.Standardization of the technique of epicotyl and softwood grafting in jack (Artocarpus heterophyllus Lam.). South Indian Hort. J., 39: 264-267.

Maiti, C. S. and Sen, S.K. 1999. Effect of pretreatments of scion on grafting success in Jack fruit (Artocarpus heterophyllus L.), Hort. J., 12 (2): 97-99.

Prajapati, G. K. Patel, M. M., Bhadauria, H. S., Varma, L. R., Modi, D. J. and V.R. Garasiya. 2014. Study of softwood grafting on different mango varieties. Asian J. of Hort., 9: 240-242.

Priyanka H.L., Vinay G.M., Hipparagikulapati, Deepak, G., Nayan Mamatha, N. P. 2017. Effect of rootstocks age on softwood grafting in jackfruit (Artocarpus heterophyllus Lam.). Inter. J. of Agri. Sci., 9 (12): 4043-4044.

Selvi, R., Kumar, N., Selvarajan, M. and Anbu. S. 2008. Effect of environment on grafting success in jackfruit. Indian $\mathbf{J}$. Hort., 65(3): 341-343.

Swamy, G.S.K. 1993. Standardization of vegetative propagation techniques in jack fruit (Artocarpus heterophyllus Lam.). Ph.D. Thesis, Univ. Agric. Sci., Bangalore.

\section{How to cite this article:}

Naik, K.E. and Subesh Ranjith Kumar, C. 2018. Effect of Different Age of Rootstock on Grafting of Jackfruit (Artocarpus heterophyllus L.) var.Palur-1. Int.J.Curr.Microbiol.App.Sci. 7(08): 39943998. doi: https://doi.org/10.20546/ijcmas.2018.708.413 